\title{
Construction and Practice of Advanced Mathematics Curriculum Applicable to Undergraduate Economics Majors
}

\author{
Zhao Jiayin ${ }^{1}$ Lv Wei ${ }^{2}$ Zhang Xiaoqiao ${ }^{1}$ Huang Qun ${ }^{1}$ Bi Jing ${ }^{1}$ \\ ( ${ }^{1}$ Beijing City University, Beijing, 100083) \\ $\left({ }^{2}\right.$ Beijing Institute of Economic Management, Beijing, 100102)
}

\begin{abstract}
For the purpose of constructing advanced mathematics course group for undergraduate economics majors, the thesis discusses the teaching reform that centers on transferring the focus of the advanced mathematics course group of applicationoriented universities from "mathematical calculation" to "application of mathematics". The thesis covers the reform practiced in different aspects, from curriculum orientation and teaching model to assessment and evaluation system, of the advanced mathematics course group offered to Beijing City University (BCU) undergraduate economics majors. As a trial reform, the practice has achieved good effects.
\end{abstract}

Keywords: Talent with practical abilities, Advanced mathematics curriculum, Teaching model, Assessment and evaluation

\section{Research Background}

According to the educational reform spirit specified in the National Outline for Medium-and-Long Term Educational Reform and Development and Views of Beijing City University Towards Revising Training Programs for Undergraduate Talents, BCU revised in 2010 its talent training program for undergraduate finance majors. The 2010 revision locates the talent training objective as fostering talents with practical abilities, aiming to cultivate their independent study ability, independent thinking ability, information processing ability, lifelong learning ability, and research and innovation ability.

Traditional university mathematics courses for majors in economy are mostly theoretical. Such contents overemphasize how to "calculate with mathematics", which results in mathematics courses drifting away from follow-up major courses. Obviously, this is contradictory to the objective of fostering talents with practical abilities.

This paper, revolving around the construction of advanced mathematics curriculum for BCU financial majors, mainly describes in detail the relevant construction plan and its implementation objective. The paper also discusses the ideas of reforming college mathematics curriculum offered to BCU economics majors from the aspect of cultivating students' application abilities.

\section{Construction Plan of Applied Eco- nomic Mathematics Course Group}

Today, with the popularization of higher education, the values of China's college general education courses are transforming from knowledge-oriented to publicoriented $^{[1,2]}$ and students-oriented ${ }^{[3]}$. Like major courses, general education 
courses are exploring new ways of reform and reintegration.

\subsection{Adjusting Course Orientation}

To meet the needs of cultivating practical talents, BCU transformed mathematics course from a general education course to a basic major course when revising its training programs for professional talents.

Taking the construction of mathematics courses for financial majors as trial and following these practical questions including "Why do we set a mathematics course in this major?", "What kind of mathematical knowledge do students need?", "What kind of role does this course play in realizing the training objective?", we conduct surveys on students, math teachers, teachers of major courses, and other staff, and finally define the mathematics courses for BCU financial majors as "taking the preparation for follow-up courses as the basis, the cultivation of students' abilities to make use of math knowledge and methods to solve practical problems in economic field as the goal, and the improvement of each student's ability in studying independently and the development of each student compared to previous performance as the fundamental objective".

\subsection{Reconstruction of Teaching Model}

Teaching model is a formula or plan consisting of courses, assignment, textbook selection, and teaching activities ${ }^{[4]}$.

This paper suggests that the new teaching model, of which "Guided by teacher, Student-centered, Application dominates", should be adopted. Under the old model, students passively receive knowledge or mechanically memorize what they learn. Under the new model, students are guided or required to discuss, study independently, or to process, reintegrate, and reprocess the information before delivery. As such, students interact with the teacher actively in the process of learning and at the same time, becoming aware of where what they learn is applicable. The new teaching model fully represents students' central position in learning process.

Table 1 shows that difference of teaching models before and after construction of course group.

Table 1. Difference of teaching models before and after construction of course group

\begin{tabular}{l|l}
\hline $\begin{array}{l}\text { Original Teaching } \\
\text { Model }\end{array}$ & $\begin{array}{l}\text { The New Teaching } \\
\text { Model }\end{array}$ \\
\hline Teacher-centered & $\begin{array}{l}\text { Guided by teacher, } \\
\text { Student-centered, } \\
\text { Application domi- } \\
\text { nates }\end{array}$ \\
\hline $\begin{array}{l}\text { Chapter Teaching: } \\
\text { listing of knowledge } \\
\text { points }\end{array}$ & $\begin{array}{l}\text { Task-based teaching: } \\
\text { knowledge combina- } \\
\text { tion }\end{array}$ \\
\hline $\begin{array}{l}\text { The old teaching per- } \\
\text { spective: } \\
\text { inability to use after } \\
\text { learning }\end{array}$ & $\begin{array}{l}\text { Integration with ma- } \\
\text { jor courses: } \\
\text { mastery and practical } \\
\text { use of knowledge }\end{array}$ \\
\hline $\begin{array}{l}\text { One-way teaching: } \\
\text { passive learning }\end{array}$ & $\begin{array}{l}\text { Diversified learning: } \\
\text { motivated learning; } \\
\text { fostering of innova- } \\
\text { tive thinking }\end{array}$ \\
\hline $\begin{array}{l}\text { Theoretical teaching: } \\
\text { absence of practical } \\
\text { application; } \\
\text { emphasis on ques- } \\
\text { tion-solving skills }\end{array}$ & $\begin{array}{l}\text { Integration of theories } \\
\text { and practice: } \\
\text { learning to solve } \\
\text { questions using math } \\
\text { software and all- } \\
\text { process simulated } \\
\text { training }\end{array}$ \\
\hline $\begin{array}{l}\text { Assessment and } \\
\text { evaluation: } \\
\text { summative assess- } \\
\text { ment; } \\
\text { incapability to assess } \\
\text { students' application } \\
\text { ability }\end{array}$ & $\begin{array}{l}\text { uation: } \\
\text { summative assess- } \\
\text { ment + process as- } \\
\text { sessment; } \\
\text { integration of learn- } \\
\text { ing, practice, assess- } \\
\text { ment }\end{array}$ \\
\hline
\end{tabular}

We can see from Fig 1 that, mathematics courses do not solely emphasize the training of logic thinking and problemsolving skills. Under the guidance of "application-oriented", the focus of the courses has now shifted to the practical application of mathematics knowledge to major matters. The new model has real- 
ized the integration of theory and practice, teaching and learning by introducing into the classroom mathematics training software package and math experiments that help dealing with mathematical calculation. The new model has guided students to put emphasis on "using math" instead of "calculating numbers".

\subsection{Construction of Assessment System}

Applied economic mathematics course group attaches great importance to test students' capacity in solving economic problems with the knowledge of mathematics. The assessment are carried out through the integration of two ways, procedural assessment and terminal assessment, that is, in terms of contents of assessment, theory and application should be combined, and in-class teaching and after-class self-study combined; in terms of assessment methods, close-book assessment and open-book assessment should be combined, and individual and group combined.

Open-book assessment is conducted in group. The results of assessment depend on two aspects, group average grade given according to the completion of the task, and individual grade given with proper adjustment on the basis of group average grade according to the role each member plays in the group as well as the completion of the task. Group average grade is a key method to test student's team spirit, while each individual's grade a key method to test student's ability in independent thinking and innovation. Diversified assessments not only boost student's interest in study, but also indicate the transformation to student-orientation in teaching ideas.

\section{Implementation Objective of Ap- plied Economic Mathematics Course Group}

\subsection{Emphasizing Practical Use, Im- prove Student's Ability in Solving Problems}

Traditional teaching of limit, derivative, extremum, integration, numerical characteristics of random variables and other contents mainly emphasizes the understanding of concepts and the training on the skills of calculation; while the teaching through applied economic mathematics course group mainly focuses on the cultivation of student's practical ability in using mathematical knowledge to solve problems. Via the study of course group, students will master the knowledge of continuous compounding, margin and elasticity, optimization, consumer surplus, expected revenue and risk in economy.

We transform the training on "calculation skills" to the improvement on "practical ability" by adding practice hour to the course and introducing mathematics software package for practical training and mathematics experiments to class, which will save much time and efforts compared to manual calculation and will improve students' capacity in information processing. For example, introduce mathematics software Mathematica in Applied Economic Mathematics First, which will help with the calculation of calculus; introduce Excel in Applied Economic Mathematics Second, which will help with the solution of mathematical model of linear programming; introduce excel in mathematical statistics of Applied Economic Mathematics Third, which will help students learn the methods of doing interval estimation, hypothesis test and regression analysis with the help of software. 


\subsection{Increase Group Discussions, Culti- vate Student's Ability in Teamwork}

We give full play to student's dominant role in study; before a course begins, the students need to form self-study group voluntarily, usually 4 to 6 students a group; they can discuss with each other in daily time and receive assessment on contents learned through self-study in final exam as a group. In the class, combining with group discussion, teachers point out key questions for students, and instruct them to read the text book, to learn independently around the question, and to discuss in group; in this way, students can master knowledge points and exercise their abilities in the process of seeking for the answer and answering the questions. After the class, teachers assign comprehensive questions, students have to check, collect and categorize relative materials by themselves and then hand in their assignments. Students don't have to get terminal conclusion, in other words, their answers could be open-ended. The method not only boosts student's initiative in attending teaching activities but also enhances their ability in team work.

\subsection{Organize Students to Attend Com- petition, Cultivate Students' Innovative Ability}

In recent years, our university gives high priority to "National Undergraduate Mathematical Modeling Competition"; we open courses to train students in the third semester. In 2012, our university organized ten groups to participate in the competition, and won the second place in Undergraduate Group of Beijing Division of National Undergraduate Mathematical Modeling Competition. It indicates that our students have a solid mathematical background, strong persistence, innovative mind and a spirit of team work.

\section{Conclusion}

We chose 645 students from 17 classes of three different grades as experimental objects in the construction and application of applied economic mathematics course group. The initial results showed that the course group was highly approved by students and teachers of follow-up courses, increased students' initiative and confidence in study, effectively laid foundation for the study of follow-up courses, enhanced the innovation of teaching contents, teaching methods, and teaching aids of mathematics course in applicationoriented universities, strengthened the cultivation of students' ability in practice, self-study, teamwork and innovation. The achievement will be further applied to educational reforms in other majors in order to fully display the teaching ideas of Beijing City University characterized by "adaptability, comprehensiveness, efficiency, practicability" as well as the "people-oriented" values in education.

\section{References:}

[1] Wang Chunling. Comparison Between Education of Individual-Based Theory and Public-Based Theory [J]. Academic Journal of Mudanjiang Institute of Education 2012(2).

[2] Pan Xiangming, Lv Xianzhi. Value Orientation of Case Teaching Education-Integration of Public Standard and Individual Standard [J]. Academic Exploration, 2011(4).

[3] Cheng Liping, Liu Ruiguo. Research on "Student-Oriented" Teaching Model in University [J]. China Electrical Education, 2009(12)

[4] Joyce Brece, Weil Marsha. Conceptual Complexity, Teaching Style and Models of Teaching[DB/OL]. 